\title{
Effect of semi-occluded vocal tract exercise via telepractice on subjective voice evaluation of early childhood teachers*
}

\author{
Hyeong Sun Ryu $\cdot$ Jaeock Kim** \\ Major in Speech Pathology Education, Graduate School of Education, Kangnam University, Yongin, Korea
}

\begin{abstract}
This study examines the effectiveness of semi-occluded vocal tract exercise (SOVTE) conducted through telepractice for 10 female teachers who have experienced vocal discomfort while working in early childhood education facilities (childcare centers, kindergartens). The effects of SOVTE conducted through telepractice were evaluated based on the Korean voice handicap index (KVHI), the Korean version of the voice activity and participation profile (K-VAPP), vocal effort, and auditory perception evaluation by using the grade, roughness, breathiness, asthenia, and strain (GRBAS) scale. The results show that total, functional, and physical scores of KVHI significantly reduced after SOVTE. The total score in K-VAPP significantly reduced after SOVTE. Moreover, vocal effort significantly decreased after SOVTE. However, statistically significant differences were not noted in GRB scales before and after SOVTE. In conclusion, early childhood teachers experienced reduced vocal discomfort SOVTE conducted through telepractice. The study results indicate that voice therapy conducted through telepractice is an effective method for reducing vocal discomfort in early childhood teachers.
\end{abstract}

Keywords: semi-occluded vocal tract exercise, telepractice, professional voice users, early childhood teacher

\section{1. 서론}

음성을 전문적으로 사용하는 사람을 직업적 음성사용자 (professional voice user)라고 하며, 직업적 음성사용자에는 교사, 가수, 아나운서, 성악가, 목사, 텔레마케터, 정치가 등이 해당한 다(Irving et al., 1997). 직업적 음성사용자들은 음성문제를 경험 하는 비율이 $80 \%$ 로 일반인에 비해 높다. 또한 이들은 생계 및 자기만족을 위해 음성을 부분적 또는 전적으로 의존해 사용하 기 때문에 음성 오용(misuse)과 남용(abuse)이 발생할 수 있으며,
충분한 음성 휴식을 취하지 못한다(Wingate et al., 2007). 국내에 서 교사 직업군을 대상으로 실시한 음성장애와 악화요인에 관 한 연구에 의하면 교사 914 명 중 820 명 $(89.7 \%)$ 이 자신의 음성에 문제가 있음을 인지하고 있었으며, 1 개월 이상 음성에 문제가 지속된 경우가 161 명(19.6\%), 5년 이상 지속된 경우가 26 명 $(3 \%)$ 이었고, 이로 인해 이비인후과의 진료를 받은 경우가 330 명 $(40 \%)$ 이라고 하였다(Kim et al., 2004). 즉 직업적 음성사용자, 특 히 교사들은 음성 오· 남용으로 인해 음성문제 발생 비율이 높 음에도 불구하고 음성문제에 적극적으로 대처하는 비율이 적

\footnotetext{
* This work is the modification of the first author's master thesis.

** plmcce@naver.com, Corresponding author

Received 30 October 2021; Revised 11 December 2021; Accepted 13 December 2021

(c) Copyright 2021 Korean Society of Speech Sciences. This is an Open-Access article distributed under the terms of the Creative Commons Attribution NonCommercial License (http://creativecommons.org/licenses/by-nc/4.0) which permits unrestricted non-commercial use, distribution, and reproduction in any medium, provided the original work is properly cited.
} 
다는 것을 알 수 있다. 교사 중에서도 영유아를 대상으로 하는 교사들은 영유아의 특성으로 인해 높은 음도와 강도로 음성을 사용하는 경우가 많다(Luce et al., 2014). 이로 인해 영유아 교사 들의 음성문제 발병률은 높을 수밖에 없고, 음성문제는 이들의 말명료도를 감소시켜 영유아 교육에도 부정적인 영향을 미칠 수 있다(Pyo, 2008).

2019년부터 발생한 코로나바이러스감염증-19(Corona Virus Disease 2019, 이하 COVID-19)는 비말을 통한 감염의 위험률이 높아 기존의 면대면으로 실시되던 음성치료가 원활하게 이루 어지기 어렵다. 이에 장소와 상관없이 비대면으로 언어치료를 진행할 수 있는 통신 기술과 의사소통 기술을 접목시킨 언어치 료서비스로 원격치료(telepractice)가 대면치료의 대안으로 많은 관심을 얻고 있다(ASHA, 2021). 미국언어청각학회(American Speech-Language-Hearing Association, ASHA)는 원격치료가 대 면치료만큼 효과적인 치료임을 여러 차례 증명하였으며, Allik et al.(2006)과 Brennan \& Barker(2004)의 연구에서도 대상자들 대부분이 대면치료만큼 원격치료에 대해 높은 만족도를 보였 을 뿐 아니라 전문가와 보호자도 기존의 치료보다 더 높은 만족 도를 나타냈다.

원격치료를 이용한 음성치료로 발성 시 호흡, 발성, 공명의 하 부체계의 문제를 통합적으로 접근하는 반폐쇄성도훈련(semioccluded vocal tract exercise, SOVTE)을 적용할 수 있다. SOVTE 는 대상자 스스로 자가훈련을 할 수 있기 때문에 원격치료를 통 해 언어재활사로부터 적절한 훈련과 피드백이 이루어진다면 매우 효율적으로 수행될 수 있다. SOVTE는 성도를 부분적으로 폐쇄한 상태에서 발성하는 훈련법으로, 구강이 부분적으로 닫 힐 때 후두의 위치는 낮추고 인두는 넓히며, 구강의 상태, 모양, 개방정도 등에 따라 다양하게 후두 상부를 좁혀 성문상압과 성 문하압과의 차이를 발생시키며, 성대가 적은 노력으로 보다 효 율적이고 경제적으로 진동할 수 있도록 한다(Titze, 2006). SOVTE는 후두 병변이 없는 성악가들에서 즉각적인 목소리 개 선 효과가 있는 것으로 보고되고 있다(Fadel et al., 2016). 과기능 적 음성장애 환자를 대상으로 한 연구에서도 첫 회기 음성치료 이후 다수의 대상자들에서 발성기관의 과긴장이 이완되고 청 지각적으로 음성의 개선이 나타나 매우 유용한 음성치료 방법 임을 시사하고 있다(Kim et al., 2019).

다만 음성치료를 원격으로 수행될 경우 음성개선 정도를 확 인하기 위한 음성검사는 제한적이다. 대면으로 음성검사가 이 루어질 때는 기기를 이용한 음향학적, 공기역학적, 후두내시경 을 이용한 시각적 검사 등의 다양한 평가 방법이 있지만 원격치 료에서 실시할 수 있는 음성검사는 대상자가 증상 개선의 정도 를 주관적으로 평가하는 심리측정적 평가나 검사자가 산출된 음성을 듣고 평가하는 청지각적 평가로 제한된다(Pyo \& Song, 2010).

주관적 심리측정적 평가는 대상자가 자신이 직접 느끼고 경 험한 음성장애의 정도를 주관적으로 평가하는 방법으로, 객관 적으로 평가된 음성문제의 정도와 차이가 있을 수 있으나, 자신 의 음성문제가 일상생활에 미치는 영향을 평가할 수 있어서 실
제 생활에서의 어려움 등을 파악하는 데 도움을 준다. 주관적 심리측정적 평가 방법으로는 음성문제가 대상자의 음성사용에 있어 장애라고 느끼는 정도를 측정하는 한국어판 음성장애지 수(Korean voice handicap index, KVHI; Kim et al., 2007), 음성문 제가 음성 활동과 참여에 제약을 미치는 정도를 평가하는 음성 활동 및 참여 프로파일-한국판(Korean version of the voice activity and participation profile, K-VAPP; Lee et al., 2016), 모음, 문장, 대화 등 발화 상황에서 음성 산출 시 드는 노력과 긴장을 평가하는 음성노력도 등이 있다(Baldner et al., 2015).

청지각적 평가로는 대표적으로 GRBAS 척도(Hirano, 1981)가 사용되는데, 1975 년 일본음성언어의학회에서 이를 제안하였으 며(Sohn, 2008), 모음연장발성, 문장 읽기, 자발화 등 다양한 상 황에서 측정이 가능하다. 또한 구조가 단조롭고 평가항목이 적 어서 쉽고 빠른 평가가 가능하다는 장점이 있다(Yoo et al., 2015).

앞에서 언급한 바와 같이 영유아 교사의 경우 음성 오 - 남용 으로 인한 음성문제가 발생하는 경우가 많다. 이들의 음성은 단 순히 의사소통의 수단을 넘어 중요한 직업적 수단이기 때문에 적절한 음성관리와 치료가 필요하다. 그러나 최근의 COVID-19 와 같은 상황에서 대면으로 음성치료가 수행되기 어렵기 때문 에 원격을 통한 비대면 치료가 대안이 될 수 있다.

이에 본 연구는 직업적 음성사용자 중 음성사용의 불편감을 경험하는 영유아 교사를 대상으로 일상생활에서 쉽게 적용할 수 있는 SOVTE를 원격으로 실시하여 이들이 주관적으로 느끼 는 음성개선의 효과와 청지각적으로 평가된 음질에 미치는 효 과를 살펴보고자 한다.

이에 연구문제는 다음과 같다.

1. 음성사용의 불편감을 경험하는 영유아 교사에게 실시한 원격 SOVTE가 대상자 자가 음성평가(KVHI, K-VAPP, 음 성노력도)에 영향을 미치는가?

2. 음성사용의 불편감을 경험하는 영유아 교사에게 실시한 원격 SOVTE가 청지각적 음성평가 $(\mathrm{G}$ 척도, $\mathrm{R}$ 척도, $\mathrm{B}$ 척도) 에 영향을 미치는가?

\section{2. 연구 방법}

\section{1. 연구 대상}

본 연구는 영유아 교육시설(어린이집, 유치원)에 재직 중이 며 음성사용의 불편감을 호소하는 20-50세의 여성 교사 11 명을 대상으로 하였다. 이들의 음성사용의 불편감을 판별하기 위해 $\mathrm{KVHI}(\mathrm{Kim}$ et al., 2007)를 실시하였고, 모든 대상자가 Lee \& $\operatorname{Kim}(2020)$ 에서 $\mathrm{KVHI}$ 의 음성장애 분류 기준점(cut-off point)으 로 제시한 12.1점 이상을 충족하여 SOVTE를 이용한 원격치료 를 실시하였으나, 1 명이 사후 평가를 실시하지 않아 최종적으 로 연구 자료에 포함된 대상은 10 명이다. 
2.2. 연구 도구

\subsection{1. 대상자 자가 음성평가}

대상자 자가 음성평가는 음성으로 인한 장애정도를 평가하 는 KVHI(Kim et al., 2007)와 음성이 활동이나 참여에 영향을 미 치는 정도를 평가하는 K-VAPP(Lee et al., 2016b)로 평가하였으 며, 이들은 원격 SOVTE를 실시하기 전과 후에 각각 평가하였 다. 또한 대상자가 발화 상황에서 목소리를 산출하는데 드는 노 력과 긴장을 주관적으로 평가하는 음성노력도(Baldner et al., 2015)를 연구가 진행되는 30 일 동안 매일 실시하도록 하였다.

\subsection{2. 청지각적 평가}

대상자는 주변이 조용한 공간에서 $30 \mathrm{~cm}$ 떨어진 거리에 스마 트폰 녹음기를 설치한 후, 모음연장발성과 가을문단(Kim, 1996) 읽기를 실시하고 녹음하였다. 연구자들은 대상자가 녹음한 음 성샘플을 청지각적으로 평가하였다. GRBAS 척도에서 신뢰성 이 낮고 판정 오차가 비교적 큰 Asthenic(A), Strained(S) 2개 항 목을 제외하고 전반적인 음성 정도를 나타내는 $\operatorname{Grade}(\mathrm{G})$, 거친 정도를 나타내는 Rough(R), 기식성 정도를 나타내는 Breathy(B) 의 3 개 항목을 0.5 점 간격으로 0 점(정상, normal)부터 3 점(심함, severe)까지 7점 척도로 평가하였다.

\section{3. 연구 절차}

대상자의 모든 정보 및 자료 수집은 강남대학교 기관생명윤 리위원회의 심의를 받아 진행하였으며(KNU-HR2004005), 원격 SOVTE 프로그램은 1 개월간 주 2회 간격으로 40 분씩 총 8 회를 실시하였다.

모든 활동은 화상 강의 프로그램 Zoom(Zoom Video Communications, San Jose, CA, USA)을 이용하여 연구자와 대상자 모두 노트북으로 진행하였으며, SOVTE 프로그램은 Park et al.(2004) 에서 제시한 음성위생과 관리법을 교육한 후에 Lee et al.(2016a) 에서 제시한 자세교정을 일차적으로 실시하였다. 이와 동시에 복식호흡과 이완훈련을 실시하였다. 음성위생은 자제해야 하 는 행동(큰 소리 내거나 소리 지르기, 속삭이기, 헛기침하기, 카 페인 섭취 음주 및 흡연, 과다음식 섭취 및 수면 전 음식 섭취 등)과 바람직한 행동(습도 유지, 충분한 물 섭취, 조용한 기침, 수면습관 등)을 포함하며, 매 회기마다 교육하고 확인하였다.

모든 SOVTE 프로그램의 훈련과정은 연구자와 5명의 대상 자를 그룹으로 하여 총 2 개 그룹에서 실시되었고, 그룹훈련을 실시하는 동안 SOVTE의 각 단계에서 연구자는 대상자 한 명씩 일대일 개별적인 피드백을 통해 SOVTE를 정확하게 실시하도 록 하였다. SOVTE 프로그램은 Kim et al.(2019)과 Meerschman et al.(2017)에서 제시한 방법을 사용하였다. 우선 입술 트릴과 비강자음을 이용한 허밍발성, 양순유성마찰음[비을 각각 2 분 이내로 실시한 후 자체 제작한 $500 \mathrm{~mL}$ 텀블러와 튜브를 이용하 여 Lax Vox를 실시하였다. Lax Vox는 3-8회기 동안 진행하였으 며, 실리콘 튜브의 직경은 $1.2 \mathrm{~cm}$, 길이가 $30 \mathrm{~cm}$ 로 3-5회기는 3 $\mathrm{cm}, 6-8$ 회기는 $7 \mathrm{~cm}$ 깊이로 텀블러에 넣어 진행하였다.
SOVTE 프로그램의 단계는 표 1에 제시하였다. 1 단계는 무발 성 거품내기를 실시하였다. 물병을 대상자의 가슴 앞쪽에 두고 실리콘 튜브를 입안으로 넣고 치아와 혀 위에 위치시키고 물병 에 실리콘 튜브를 1-2 cm 정도 넣은 후 숨을 내쉬면서 물거품을 만들도록 하였다. 2 단계는/우/ 발성과 함께 최적의 음성을 유도 하였다. 3 단계는 한 옥타브 안에서 한 음씩 내리거나 올리면서 각 음에서 연장발성을 실시하였다. 다음으로 활창하기(gliding) 로 음도 상승과 하강 및 스타카토(staccato) 연습으로 음을 올리 거나 내린 다음 간단한 노래 부르기(“나비야”, “학교 종”, “비행 기”)를 하였다. 마지막으로 일반화를 위해 물병으로부터 서서 히 실리콘 튜브를 빼면서/우/ 발성을 유지하게 하고 실리콘 튜 브가 없는 상태에서 한 옥타브 안에서 음을 올리거나 내리며 발 성 연습을 진행하였다.

2.4. 자료 분석

\subsection{1. 대상자 자가 음성평가}

$\mathrm{KVHI}$ 는 총 점수 $\left(\mathrm{KVHI}_{\mathrm{TTL}}\right)$ 와 세 하위영역인 신체적 영역 점수 $\left(\mathrm{KVHI}_{\mathrm{P}}\right)$, 기능적 영역 점수 $\left(\mathrm{KVHI}_{\mathrm{F}}\right)$, 정서적 영역 점수 $\left(\mathrm{KVHI}_{\mathrm{E}}\right)$ 를 각각 산출하였다.

$\mathrm{K}-\mathrm{VAPP}$ 는 총점 $\left(\mathrm{K}-\mathrm{VAPP}_{\mathrm{TTL}}\right)$ 과 다섯 개의 하위문항(1. Severity, 2. Job, 3. Daily, 4. Social, 5. Emotion) 중에서 직업에 대한 영향 (2. Job), 일상 의사소통에 대한 영향(3. Daily), 사회적 의사소통 에 대한 영향(4. Social)은 활동 제한 항목과 참여 제약 항목의 점 수를 포함시켜 활동 제한 점수 $\left(\mathrm{K}-\mathrm{VAPP}_{\mathrm{ALS}}\right)$ 와 참여 제약 점수 $\left(\mathrm{K}-\mathrm{VAPP}_{\mathrm{PRS}}\right)$ 를 산출하였다. 또한 목소리 문제의 심각한 정도에 대 한 본인의 인식 $\left(\mathrm{K}-\mathrm{VAPP}_{\mathrm{I}}\right)$ 과 본인의 감정에 대한 영향 $\left(\mathrm{K}-\mathrm{VAPP}_{\mathrm{V}}\right)$ 은 각 하위문항 점수만을 산정하였다(Lee et al., 2016b). KVHI와 $\mathrm{K}-\mathrm{VAPP}$ 는 SOVTE를 실시하기 전과 후의 점수를 비교하였다.

음성노력도는 0-10점이며 0.5점이 추가된 12점 척도로 구성되 어 있고, 음성 산출 시 노력과 긴장을 평가한다. 대상자가 SOVTE 를 실시하는 30 일 동안 매일 평가한 점수를 주차별로 평균값을 산출하였고, SOVTE 실시하기 전과 후의 점수를 비교하였다.

표 1. 원격 SOVTE 프로그램

Table 1. Program of SOVTE via telepractice

\begin{tabular}{c|l|c}
\hline Program & \multicolumn{1}{|c|}{ Methods } & Session \\
\hline \multirow{2}{*}{ Warm-up } & $\begin{array}{l}\text { Vocal hygiene } \\
\text { Posture correction } \\
\text { Abdominal breathing \& relaxation }\end{array}$ & $1-8$ \\
\hline \multirow{5}{*}{ SOVTE } & $\begin{array}{l}\text { Lip trill } \\
\text { Humming } \\
\text { Voiced bilateral fricative [ } \beta \text { : }\end{array}$ & \multirow{2}{*}{$3-8$} \\
\cline { 2 - 3 } & $\begin{array}{l}\text { Lax Vox } \\
\text { 1st step: Bubbbling without phonation } \\
\text { 2nd step: Guiding optimal voice } \\
\text { 3rd step: Sustained phonation, gliding, } \\
\text { staccato, singing, and generalization }\end{array}$ & \\
\hline \multicolumn{2}{|c|}{ Self training (Lax Vox) } & $\begin{array}{c}\text { 20 min } \\
\text { every day }\end{array}$ \\
\hline
\end{tabular}

SOVTE, semi-occluded vocal tract exercise. 


\subsection{2. 청지각적 평가}

GRBAS 척도를 이용하여 모음연장발성과 문단읽기에서 각 각 $\mathrm{G}, \mathrm{R}, \mathrm{B}$ 의 점수를 평가하였으며, 이를 비교하여 두 점수가 상 이할 경우 중증도가 높게 평가된 점수를 사용하여 SOVTE 실시 전과 후의 점수를 산출하였다.

\subsection{3. 자료의 통계적 처리}

본 연구에서 수집된 자료는 통계분석 프로그램 SPSS 21.0 ${ }^{\mathrm{TM}}$ (IBM Statistics Package for Social Science version 21.0)을 이용하 였고, 유의수준은 0.05 로 하였다. 평가를 통해 산출된 13 개의 변 수 $\left(\mathrm{KVHI}_{\mathrm{TTL}}, \mathrm{KVHI}_{\mathrm{F}}, \mathrm{KVHI}_{\mathrm{P}}, \mathrm{KVHI}_{\mathrm{E}}, \mathrm{K}-\mathrm{VAPP}_{\mathrm{TTL}}, \mathrm{K}-\mathrm{VAPP}_{\mathrm{ALS}}\right.$, $\mathrm{K}_{-V A P P} \mathrm{PRS}_{1}, \mathrm{~K}^{-V A P P} \mathrm{I}_{\mathrm{I}}, \mathrm{K}-\mathrm{VAPP}_{\mathrm{V}}$, 음성노력도, $\left.\mathrm{G}, \mathrm{R}, \mathrm{B}\right)$ 는 비모 수 검정인 윌콕슨 부호 순위 검정(Wilcoxon signed rank test)으로 사전과사후를 비교하였다.

\section{5. 신뢰도 평가}

청지각적 평가의 평가자 내 신뢰도 분석을 위해 제 1 저자가 사전과 사후에 걸쳐 녹음된 전체 음성샘플에 대해 재평가를 실 시하였으며, 2회에 걸쳐 평가한 결과를 스피어만 상관분석 (Spearman correlation)으로 분석하였다, 사전검사에서 $\mathrm{G}$ 척도, $\mathrm{R}$ 척도, $\mathrm{B}$ 척도의 상관계수는 각각 $.949, .964, .907$ 였고, 사후검사 에서는 각 $.922, .900, .968$ 로 통계적으로 유의미하게 신뢰도가 높았다 $(p<.01)$.

청지각적 평가의 평가자 간 신뢰도는 제 1 저자와 음성장애 전 공 언어병리학과 교수인 교신저자가 사전과 사후에 걸쳐 녹음 된 전체 음성샘플에 대해 각자 개별적으로 평가하고, 이를 스피 어만 상관분석을 통해 검정하였다. 사전검사에서 $\mathrm{G}$ 척도, $\mathrm{R}$ 척 도, $\mathrm{B}$ 척도의 상관계수는 각각 $1.000,1.000, .918$ 이었으며, 사후 검사에서는 각각 $.945 .721, .902$ 로 통계적으로 유의미하게 신뢰 도가 높았다 $(p<.01)$.

\section{3. 연구 결과}

3.1. 원격 SOVTE 실시 전과 후의 대상자 자가 음성평가 비교

\subsection{1. 원격 SOVTE 실시 전과 후의 $\mathrm{KVHI}$ 비교}

원격으로 SOVTE를 실시하기 전과 후의 $\mathrm{KVHI}$ 를 비교한 결 과는 표 2와 같다.

원격 SOVTE를 실시하기 전(중위수 20.5점)에 비해 실시 후 (중위수 11 점)에 $\mathrm{KVHI}_{\mathrm{TTL}}$ 는 유의미하게 낮아졌다 $(Z=-2.207$, $p=.027)$. 또한 $\mathrm{KVHI}_{\mathrm{F}}$ 와 $\mathrm{KVHI}_{\mathrm{P}}$ 도 $\mathrm{SOVTE}$ 실시 전(각 중위수 6.5 점과 12 점)에 비해 실시 후(각 중위수 3점과 7.5 점)에 유의하게 낮아졌다 $(Z=-2.207, p=.027)$. 다만 $\mathrm{KVHI}_{\mathrm{E}}$ 의 경우 점수는 $\mathrm{SOVTE}$ 실시 전(중위수 2.5 점)보다 실시 후(중위수 1점)에 낮아졌으나 통계적으로 유의한 차이는 없었다.
표 2. 원격 SOVTE 실시 전과 후의 $\mathrm{KVHI}$

Table 2. KVHIs of pre- and post-SOVTE via telepractice

\begin{tabular}{|c|c|c|c|c|c|c|c|c|}
\hline \multirow{3}{*}{$\begin{array}{l}\text { 백분 } \\
\text { 위수 }\end{array}$} & \multicolumn{8}{|c|}{ KVHI } \\
\hline & \multicolumn{3}{|c|}{ Pre } & \multicolumn{3}{|c|}{ Post } & \multirow[t]{2}{*}{$Z$-value } & \multirow[t]{2}{*}{$p$-value } \\
\hline & 25 & 50 & 75 & 25 & 50 & 75 & & \\
\hline TTL & 14 & 20.5 & 38 & 7 & 11 & 25 & -2.207 & .027 \\
\hline $\mathrm{F}$ & 4 & 6.5 & 11.5 & .75 & 3 & 4.75 & -2.207 & .027 \\
\hline $\mathrm{P}$ & 8 & 12 & 18.5 & 5.75 & 7.5 & 15.75 & -2.207 & .027 \\
\hline $\mathrm{E}$ & 1.5 & 2.5 & 5.5 & 0 & 1 & 3 & -1.051 & .293 \\
\hline
\end{tabular}

SOVTE, semi-occluded vocal tract exercise; KVHI, Korean voice handicap index; TTL, total score; F, functional score; P, physical score; E, emotional score.

\subsection{2. 반폐쇄성도훈련(SOVTE) 실시 전과 후 K-VAPP 비교}

원격 SOVTE를 실시하기 전과 후의 K-VAPP를 비교한 결과 는 표 3 과 같다.

SOVTE 실시 전(중위수 14점)에 비해 실시 후(중위수 6점)에 $\mathrm{K}^{-V_{A P P}}{ }_{\mathrm{TTL}}$ 은 유의미하게 낮아졌다 $(Z=-2.023, p=.043)$. 그러나

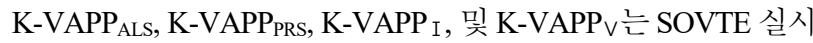
전과 후에 통계적으로 유의한 차이가 없었으나 모두 실시 전에 비해 실시 후에 중위수 점수가 낮아졌다.

표 3. 원격 SOVTE 실시 전과 후의 K-VAPP

Table 3. K-VAPPs of pre- and post-SOVTE via telepractice

\begin{tabular}{|c|c|c|c|c|c|c|c|c|}
\hline \multirow{3}{*}{$\begin{array}{l}\text { 백분 } \\
\text { 위수 }\end{array}$} & \multicolumn{8}{|c|}{ K-VAPP } \\
\hline & \multicolumn{3}{|c|}{ Pre } & \multicolumn{3}{|c|}{ Post } & \multirow[t]{2}{*}{$Z$-value } & \multirow[t]{2}{*}{$p$-value } \\
\hline & 25 & 50 & 75 & 25 & 50 & 75 & & \\
\hline TTL & .75 & 14 & 34.5 & .75 & 6 & 16.25 & -2.023 & .043 \\
\hline ALS & 0 & 3.5 & 15.5 & 0 & 1.5 & 8.75 & -1.590 & .122 \\
\hline PRS & 0 & 0 & 5 & 0 & 0 & 2.5 & -1.604 & .109 \\
\hline I & 0 & 2.5 & 4.25 & 0 & 1 & 4.25 & -1.289 & .197 \\
\hline П & 0 & 3 & 8.5 & 0 & 0 & 7 & -1.084 & .279 \\
\hline
\end{tabular}

SOVTE, semi-occluded vocal tract exercise; K-VAPP, Korean version of the voice activity and participation profile; K-VAPP, Korean version of the voice activity and participation profile; TTL, total; ALS, activity limitation score; PRS, participation restriction score; I, subcategory I score; V, subcategory V score.

3.1.3. 원격 SOVTE 실시 전과 후의 음성노력도 비교

원격 SOVTE를 실시하기 전과 후의 음성노력도를 비교한 결 과는 표 4에 제시되었다.

음성노력도는 SOVTE 실시 전(중위수 3점)에 비해 실시 후(중 위수 0.5 점)에 통계적으로 유의하게 감소하여 대상자가 목소리 를 내는 데 드는 노력과 긴장이 감소하였다 $(Z=-2.555, p=.011)$.

표 4. 원격 SOVTE 실시 전과 후의 음성노력도

Table 4. Vocal efforts of pre- and post-SOVTE via telepractice

\begin{tabular}{c|c|c|c|c|c|c|c|c}
\hline \multirow{2}{*}{$\begin{array}{c}\text { 백분 } \\
\text { 위수 }\end{array}$} & \multicolumn{7}{|c|}{ Pre } & \multicolumn{5}{c}{ Post } & $Z$-value & $p$-value \\
\cline { 2 - 9 } & 25 & 50 & 75 & 25 & 50 & 75 & & \\
\hline $\begin{array}{l}\text { Vocal } \\
\text { effort }\end{array}$ & 1.5 & 3 & 4 & 0 & .5 & 2 & -2.555 & .011 \\
\hline
\end{tabular}

SOVTE, semi-occluded vocal tract exercise 
3.2. 원격 SOVTE 실시 전과 후 청지각적 평가 비교

\subsection{1. 원격 SOVTE 실시 전과 후 $\mathrm{G}, \mathrm{R}, \mathrm{B}$ 비교}

원격으로 SOVTE를 실시하기 전과 후의 청지각적 평가인 $\mathrm{GRBAS}$ 중 $\mathrm{G}$ 척도, $\mathrm{R}$ 척도, $\mathrm{B}$ 척도의 차이를 비교한 결과는 표 5 와 같다.

원격 SOVTE를 $\mathrm{G}$ 척도, $\mathrm{R}$ 척도, $\mathrm{B}$ 척도 모두 실시하기 전(각 중 위수 1,5 점, 1.25 점, 1 점)과 실시 후(각 중위수 1 점, 1 점, 0.5 점)에 점수가 감소하긴 하였으나 통계적으로 유의한 차이는 없었다.

표 5. 원격 SOVTE 실시 전과 후의 $\mathrm{G}, \mathrm{R}, \mathrm{B}$ scales Table 5. G, R, B scales of pre- and post-SOVTE via telepractice

\begin{tabular}{c|c|c|c|c|c|c|c|c}
\hline \multirow{2}{*}{$\begin{array}{c}\text { 백분 } \\
\text { 위수 }\end{array}$} & \multicolumn{7}{|c|}{ Pre } & \multicolumn{3}{c}{ Post } & $Z$-value & $p$-value \\
\hline & 25 & 50 & 75 & 25 & 50 & 75 & & \\
\hline $\mathrm{G}$ & 1 & 1.5 & 2 & 1 & 1 & 2 & -.707 & .480 \\
\hline $\mathrm{R}$ & 1 & 1.25 & 2 & 1 & 1 & 1.625 & -.966 & .334 \\
\hline $\mathrm{B}$ & .375 & 1 & 1.50 & 0 & .5 & 1.125 & -1.406 & .160 \\
\hline
\end{tabular}

SOVTE, semi-occluded vocal tract exercise; $\mathrm{G}$, overall grade; R, roughness; B, breathiness.

\section{4. 결론 및 논의}

본 연구에서는 음성의 불편감이 있는 영유아 교사들에게 원 격으로 SOVTE를 적용하였을 때 주관적으로 평가한 음성 문제 와 청지각적으로 평가한 음질에 어떠한 영향을 미치는지를 살 펴보고자 하였다. 이를 위해 영유아 교육시설에 근무하는 2050 세의 여성 교사 10 명을 대상으로 4 주간 화상 강의 플랫폼인 Zoom을 이용하여 원격으로 SOVTE를 이용한 그룹훈련을 실시 하였고, 훈련을 실시하기 전과 후에 KVHI, K-VAPP, 음성노력 도 및 $\mathrm{G}, \mathrm{R}, \mathrm{B}$ 척도를 평가하여 비교하였다.

원격 SOVTE 실시 전과 후의 대상자 자가 음성평가를 비교한 결과, $\mathrm{KVHI}$ 는 총 점수 $\left(\mathrm{KVHI}_{\mathrm{TTL}}\right)$ 와 기능적 영역 점수 $\left(\mathrm{KVHI}_{\mathrm{F}}\right)$, 신체적 영역 점수 $\left(\mathrm{KVHI}_{\mathrm{P}}\right)$ 는 유의미하게 개선되었다. 본 연구를 통해서는 직접 확인할 수는 없지만 선행연구(Kim, 2019)에서 제 시한 바와 같이 SOVTE를 통해 발성 시 성대의 접촉면적이 증 가하고 후두가 이완됨으로써 성대가 효율적이고 경제적으로 진동하였기 때문으로 판단된다. 이러한 결과는 언어치료학과 학생을 대상으로 튜브 발성의 SOVTE를 15 분간 실시한 후에 주 관적 음성평가를 실시한 결과, 음성사용의 불편감이 개선되었 고 음질과 음성피로도 또한 개선되었다는 연구결과와도 일맥 상통한다(Sonj et al., 2018). 즉 원격으로 실시한 SOVTE 활동이 영유아 교사들의 잘못된 음성사용으로 인한 문제를 개선시키 는 데 효과가 있음을 알 수 있다. 다만, 정서적 영역 점수 $\left(\mathrm{KVHI}_{\mathrm{E}}\right)$ 의 경우 일부 대상자가 추가 업무, 가사 등으로 본 연구 에서 제시한 훈련 절차를 다소 성실히 수행하지 못했다고 보고 함으로써 본인의 불성실한 훈련으로 인해 심리적인 측면에서 의 효과가 나타나지 않았다고 판단한 것으로 보인다.

원격 SOVTE를 실시하기 전과 후의 K-VAPP를 비교한 결과, 총 점수 $\left(\mathrm{K}-\mathrm{VAPP}_{\mathrm{TTL}}\right)$ 는 유의미한 차이를 보인 반면, 활동 제약
점수 $\left(\mathrm{K}-\mathrm{VAPP}_{\mathrm{ALS}}\right)$, 참여 제약 점수 $\left(\mathrm{K}-\mathrm{VAPP}_{\mathrm{PRS}}\right)$, 하위문항 I $(\mathrm{K}-\mathrm{VAPP} \mathrm{I})$, 하위문항 $\mathrm{V}(\mathrm{K}-\mathrm{VAPP} \vee$ 는 통계적으로는 유의미한 차이가 나타나지 않았다. 이는 10 명의 적은 인원을 대상으로 하 였기 때문에 K-VAPP를 하위영역으로 구분하였을 때 각 하위영 역별로 점수가 크지 않기 때문에 원격치료 실시 전과 후의 통계 적인 유의성을 나타내지 못한 것으로 보인다.

SOVTE 실시 전과 후의 음성노력도는 통계적으로 유의미한 차이를 보였다. 이는 SOVTE를 통해 성대 진동 시 음성효율성 이 높아짐으로써 발성에 요구되는 노력이 감소하였음을 의미 한다. 이는 기존의 선행연구와도 유사한 결과를 보여준다(Chae et al., 2019).

원격 SOVTE 실시 전과 후의 청지각적 평가는 $\mathrm{G}$ 척도, R척도, $\mathrm{B}$ 척도 모두 통계적으로 유의미한 차이가 없었다. 이는 SOVTE 가 성대를 규칙적으로 진동하는데 도움을 주어 음질이 향상된 다는 메타분석 결과 $(\mathrm{Kim}, 2019)$ 와는 다르게 나타났는데, 이는 본 연구에 포함된 대상자들의 대부분이 원격 SOVTE 훈련 전 $\mathrm{G}$ 척도로 평가된 음질이 1.5 점에서 훈련 후 1 점으로 감소하여 임 상적으로는 감소하였으나 대상자의 수가 적어 통계적인 유의 성이 나타나지는 않은 것으로 보인다.

본 연구는 원격치료의 물리적인 한계로 SOVTE 실시 전과 후 의 대상자 자가 음성평가와 청지각적 평가만을 진행하였다.

주관적 심리측정적 음성평가는 직업적 특성, 목소리에 대한 민감도, 심리적 요인 등 평가자의 다양한 주관적 요소에 의해서 달라질 수 있다. 교사들에게 보고되는 음성 문제의 발생 빈도는 객관적 평가의 경우 $4.4 \%$ 에 불과하였으나 주관적 평가의 경우 $90 \%$ 에 이르는 등 주관적 심리측정적 음성평가와 객관적 평가 사이에 낮은 일치율을 보여(Marks, 1985) 객관적인 수치로 음성 의 특징을 정확하게 파악하기 위해 음향학적 평가나 공기역학 적 평가와 같은 객관적인 평가를 함께 실시할 필요가 있다.

본 연구는 대면으로 진행되어 오던 음성치료의 모든 과정을 원격으로 진행하였다. 그러나 대상자의 적극적인 참여를 기대 하기 어렵고, 직접적인 만남의 부재로 인해 호흡이나 자세교정 등을 직접 중재하기는 어렵다. 이에 후속 연구에서는 원격으로 음성치료를 제공할 때 대상자들의 적극적이고 꾸준한 참여를 유도하고, 대상자에게 충분한 정보를 제공할 수 있는 방법을 고 안할 필요가 있다.

마지막으로, 청지각적 평가는 대상자들이 각자 소지한 스마 트폰을 이용해 녹음한 음성을 사용하여 평가하였다. 그러므로 내장된 녹음기와 스피커의 성능과 상황에 따라 실제 음성과의 차이가 존재할 가능성을 배제할 수 없다. 스마트폰 녹음기를 이 용하여 음성을 평가한 선행연구에 따르면 스마트폰 녹음 시 소 음(50dB 이상)에 민감하게 반응하며, 일부 스마트폰의 경우 신 호 처리과정에서 생기는 변화가 결과에 영향을 미친다고 하였 다(Lebacq et al., 2017). 이러한 문제를 방지하기 위해 본 연구에 서는 대상자들에게 최대한 조용한 환경에서 녹음하도록 요청 하였다. 후속 연구에서는 통제된 환경에서 녹음 시에만 연구자 와 대상자들이 만나 실제 음성을 평가하거나 녹음 장비를 통일 하여 대상자 간의 발생할 수 있는 차이를 배제하는 것이 바람직 
할 것이다.

위의 결과를 종합해 볼 때, 음성에 불편감이 있는 영유아 교 사들에게 원격으로 SOVTE로 음성치료를 실시하였을 때 교사 들이 지각하는 음성의 불편감이 감소하였다. 이는 원격 음성치 료가 대상자들의 음성 개선의 효과가 있다고 지각하는 데 도움 을 준다는 것을 알 수 있다.

\section{References}

Allik, H., Larsson, J. O., \& Smedje, H. (2006). Health-related quality of life in parents of school-age children with Asperger Syndrome or High-Functioning Autism. Health and Quality of Life Outcomes, 4(1), 1-8.

American Speech-Language-Hearing Association. (2021). ASHA telepractice. Retrieved from https://www.asha.org/practice-portal/ professional-issues/telepractice/

Baldner, E. F., Doll, E., \& van Mersbergen, M. R. (2015). A review of measures of vocal effort with a preliminary study on the establishment of a vocal effort measure. Journal of Voice, 29(5), 530-541.

Brennan, D. M., \& Barker, L. M. (2004, September). An interactive telemedicine system for remote speech-language pathology treatment. The 26th Annual International Conference of the IEEE Engineering in Medicine and Biology Society (pp. 4773-4776). San Francisco, CA.

Chae, H. R., Choi, S. H., Choi, C. H., \& Lee, K. (2019). Effects of Lax Vox voice therapy on respiration and phonation in patients with Parkinson's disease. Communication Sciences \& Disorders, 24(3), 785-799.

Fadel, C. B. X., Dassie-Leite, A. P., Santos, R. S., Santos Junior, C. G., Dias, C. A. S., \& Sartori, D. J. (2016). Immediate effects of the semi-occluded vocal tract exercise with LaxVox ${ }^{\circledR}$ tube in singers. CoDAS, 28(5), 618-624.

Hirano, M. (1981). Clinical examination of voice. New York, NY: Springer Verlag.

Irving, R. M., Epstein, R., \& Harries, M. L. L. (1997). Care of the professional voice. Clinical Otolaryngology \& Allied Sciences, 22(3), 202-205.

Kim, H. H. (1996, February). Perceptual, acoustical, and physiological tools in ataxic dysarthria management: A case report. Proceedings of the KSPS Conference (pp. 9-22). Seoul, Korea.

Kim, J. O. (2019). Meta-analysis of semi-occluded vocal tract exercise studies on subjective voice evaluation. Journal of Speech-Language \& Hearing Disorders, 28(2), 1-11.

Kim, J. O., Lim, S. E., Park, S. Y., Choi, S. H., Choi, J. N., \& Choi, H. S. (2007). Validity and reliability of Korean-version of voice handicap index and voice-related quality of life. Speech Sciences,
14(3), 111-125.

Kim, J. S., Choi, S. H., Choi, C. H., \& Lee, D. W. (2019). Effect of voice therapy for persistent dysphonia following laryngeal microsurgery. Communication Sciences \& Disorders, 24(2), 525-534.

Kim, T. H., Jin, S. M., Song, Y. K., Lee, S. S., Lee, K. C., \& Kwon, K. H. (2004). Vocal problems among teachers: A review of prevalence and risk factor. Journal of the Korean Society of Laryngology, Phoniatrics and Logopedics, 15(1), 10-15.

Lebacq, J., Schoentgen, J., Cantarella, G., Bruss, F. T., Manfredi, C., $\&$ DeJonckere, P. (2017). Maximal ambient noise levels and type of voice material required for valid use of smartphones in clinical voice research. Journal of Voice, 31(5), 550-556.

Lee, S. J., Choi, H. S., Kim, H. H., Byeon, H. K., Lim, S. E., \& Yang, M. K. (2016). Korean version of the voice activity and participation profile (K-VAPP): A validation study. Соттиnication Sciences \& Disorders, 21(4), 695-708.

Lee, Y. W., \& Kim, G. H. (2020). Discriminative and predictive ability for screening the Korean dysphonic patients using self-reported questionnaires. Clinical Archives of Communication Disorders, 5(2), 85-95.

Luce, F. L., Teggi, R., Ramella, B., Biafora, M., Girasoli, L., Calori, G., Borroni, S., ... Bussi, M. (2014). Voice disorders in primary school teachers. Acta Otorhinolaryngologica Italica, 34(6), 412-418.

Marks, J. B. (1985). A comparative study of voice problems among teachers and civil service workers (Master's thesis). University of Minnesota, Minneapolis, MN.

Meerschman, I., Lierde, K. V., Peeters, K., Meersman, E., Claeys, S., \& D'haeseleer, E. (2017). Short-term effect of two semi-occluded vocal tract training programs on the vocal quality of future occupational voice users: "Resonant voice training using nasal consonants "versus "straw phonation". Journal of Speech, Language, and Hearing Research, 60(9), 2519-2536.

Park, S. S., Sim, H. S., Chung, S. M., Park, Y. H., \& Cho, S. H. (2004). The effect of vocal hygiene for the female elementary school teachers. Journal of the Korean Society of Laryngology, Phoniatrics and Logopedics, 15(1), 27-30.

Pyo, H. Y., \& Song, Y. (2010). Recent trends in evaluation and diagnosis of voice disorders: A literature review. Communication Sciences \& Disorders, 15(4), 506-525.

Pyo, H. Y. (2008). A study on the speech intelligibility of voice disordered patients according to the severity and utterance level. Speech Sciences, 15(2), 101-110.

Sohn, J. H. (2008). GRBAS and voice handicap index. Journal of the Korean Society of Laryngology, Phoniatrics and Logopedics, 19(2), 89-95.

Sonj, S. S., Moradi, N., Yazdi, M. J. S., Soltani, M., \& Latifi, M. 
(2018). Immediate effects of phonation into the tube protocol on the dysphonia severity index (DSI) and perceptual self-evaluation in future speech-language pathologists. Shiraz E-Medical Journal, 19(5), e60968.

Titze, I. R. (2006). Voice training and therapy with a semi-occluded vocal tract: Rationale and scientific underpinnings. Journal of Speech, Language, and Hearing Research, 49(2), 448-459.

Wingate, J. M., Brown. W. S., Shrivastav, R., Davenport, P., \& Sapienza, C. M. (2007). Treatment outcomes for professional voice users. Journal of Voice, 21(4), 433-449.

Yoo, J., Hwang, Y., Han, J., \& Lee, O. (2015). Voice and voice therapy. Seoul, Korea: Sigma press.

\section{- 류형선 (Hyeong Sun Ryu)}

강남대학교 교육대학원 언어치료교육전공 석사

경기도 용인시 기흥구 강남로40

Email:plmccc@naver.com

관심분야: 음성장애, 음성언어의학

- 김재옥 (Jaeock Kim) 교신저자

강남대학교 교육대학원 언어치료교육전공 교수

경기도 용인시 기흥구 강남로40

Tel: 031-280-3221

Email: jaeock@gmail.com

관심분야: 음성장애, 음성언어의학, 음성과학 


\title{
원격으로 실시한 반폐쇄성도훈련이 영유아 교사의 주관적 음성평가에 미치는 효과*
}

\author{
류 형 선·김 재 옥
}

강남대학교 교육대학원 언어치료교육전공

\begin{abstract}
국문초록
본 연구는 영유아 교육시설에서 근무하는 음성의 불편감을 호소하는 10 명의 여성 교사들을 대상으로 반폐쇄성도 훈련(semi-occluded vocal tract exercise, SOVTE)을 원격으로 실시하였을 때 주관적으로 평가하는 음성평가에 미치는 효과를 살펴보았다. 원격 SOVTE의 효과는 한국어판 음성장애지수(Korean voice handicap index, KVHI), 음성 활동 및 참여 프로파일-한국판(Korean version of the voice activity and participation profile, K-VAPP), 음성노력도 및 GRBAS 를 이용한 청지각적 평가로 평가하였다. 연구 결과, $\mathrm{KVHI}$ 의 총 점수, 기능적 점수, 신체적 점수는 원격 SOVTE를 실 시한 후에 통계적으로 유의하게 낮아졌다. 원격 SOVTE 실시 후 K-VAPP의 총 점수도 유의하게 감소하였으며, 음 성노력도 또한 유의하게 감소하였다. 그러나 GRB 척도는 원격 SOVTE 실시 전과 후 간에 통계적으로 유의한 차이 를 보이지 않았다. 본 연구를 통해 영유아 여성 교사에게 원격으로 실시한 SOVTE는 음성의 불편감을 감소시키는 데 효과적임을 입증하였으며, 원격으로 실시한 음성치료가 효과가 있음을 보여준다.
\end{abstract}

핵심어: 반폐쇄성도훈련, 원격언어치료, 전문적 음성사용자, 영유아 교사

\section{참고문헌}

김재옥(2019). 반폐쇄성도훈련의 주관적 음성평가에 대한 메타 분석. 언어치료연구, 28(2), 1-11.

김재옥, 임성은, 박선영, 최성희, 최재남, 최홍식(2007). 한국어판 음성장애지수와 음성관련 삶의 질의 타당도 및 신뢰도 연구. 음성과학, 14(3), 111-125.

김지성, 최성희, 최철희, 이동욱(2019). 후두미세수술 이후 지속 되는 발성장애의 음성치료 효과. 언어청각장애연구, 24(2), 525-534.

김태형, 진성민, 송윤경, 이승석, 이경철, 권기한(2004). 교사직업 군에서의 음성장애와 악화요인에 관한 연구. 대한음성언어학 회지, 15(1), 10-15.

김향희(1996). 운동실조형 마비성구음장애에 적용되는 지각적, 음향학적, 생리학적 도구에 관하여: 환자 사례를 중심으로, 제 2회 음성학 학술대회 자료집 (pp. 9-22).

박성신, 심현섭, 정성민, 박영학, 조승호(2004). 초등학교 여교사 를 대상으로 한 음성위생법 효과성. 대한후두음성언어의학회 지, 15(1), 27-30.

손진호(2008). GRBAS 음성평가의 음성장애지수. 대한음성언어 의학회지, 19(2), 89-95.
유재연, 황영진, 한지연, 이옥분 역(2015). 음성과 음성치료. 서울: 시그마프레스.

이승진, 최홍식, 김향희, 변형권, 임성은, 양민교(2016). 음성 활동 및 참여 프로파일-한국판(K-VAPP): 타당성 검증 연구. 언어청 각장애연구, 21(4), 695-708.

전다빈(2021). 언어재활사의 원격언어치료(Telepractice in Speech \& Language Therapy) 에 대한 인식 및 활용실태. 명지대학교 석 사학위논문.

표화영(2008). 음성장애의 중증도와 발화 수준에 따른 말명료도 의 변화 연구. 음성과학, 15(2), 101-110.

최정석, 임재열, 김영모(2013). 직업적 음성사용자의 특징. 대한 후두음성언어의학회지, 24(1), 18-22.

채혜림, 최성희, 최철희, 이경재(2019). Lax Vox 음성치료가 파킨 슨병 환자의 호흡 및 발성에 미치는 효과. 언어청각장애연구, 24(3), 785-799.

표화영, 송윤경(2010). 음성장애 진단 및 평가의 최근 연구 동향: 문헌적 고찰. 언어청각장애연구, 15(4), 506-525.

\footnotetext{
* 본 연구는 제 1 저자의 석사학위 논문을 수정한 것임.
} 